\title{
Effect of Nitrogen Application Rates on the Nitrogen Utilization, Yield and Quality of Rice
}

\author{
Hanling Liang, Shiyu Gao, Jingxuan Ma, Tian Zhang, Tianyu Wang, Shuang Zhang, Zhaoxia Wu* \\ College of Food Science, Shenyang Agricultural University, Shenyang, China \\ Email: *wuzxsau@163.com
}

How to cite this paper: Liang, H.L., Gao, S.Y., Ma, J.X., Zhang, T., Wang, T.Y., Zhang, S. and Wu, Z.X. (2021) Effect of Nitrogen Application Rates on the Nitrogen Utilization, Yield and Quality of Rice. Food and Nutrition Sciences, 12, 13-27. https://doi.org/10.4236/fns.2021.121002

Received: December 15, 2020

Accepted: January 15, 2021

Published: January 18, 2021

Copyright $\odot 2021$ by author(s) and Scientific Research Publishing Inc. This work is licensed under the Creative Commons Attribution International License (CC BY 4.0).

http://creativecommons.org/licenses/by/4.0/

\begin{abstract}
Research on the effect of the nitrogen application rate on the balance of the nitrogen utilization, yield and quality of rice is common in South China but is relatively lacking in Northeast China, especially in the Liaohe Delta. In this study, Yanfeng 47 rice was planted in Panjin city, China, to explore the effect of six nitrogen rates $(0,160,210,260,315$ and $420 \mathrm{~kg} \mathrm{~N} / \mathrm{ha})$ on the nitrogen use efficiency, rice quality and grain yield of rice plants. The results showed that the application of an appropriate nitrogen rate $(210-260 \mathrm{~kg} \mathrm{~N} / \mathrm{ha}) \mathrm{re}-$ markably increased the nitrogen use efficiency of rice plants, grain yield, rice milling quality and nutritional quality and resulted in a moderate rice eating quality. Although low nitrogen rates ( $160 \mathrm{~kg} \mathrm{~N} / \mathrm{ha}$ ) maintained a high rice eating quality, they decreased grain yield and other rice qualities, and excessive nitrogen ( $315 \mathrm{~kg} \mathrm{~N} / \mathrm{ha}$ ) increased rice appearance quality but significantly reduced the nitrogen use efficiency $(\mathrm{p}<0.05)$, yield and eating quality of rice. Therefore, to produce rice in the Liaohe Delta by an environmentally friendly method and guarantee rice with high quality and yield, the recommended nitrogen application rate is $210 \mathrm{~kg} \mathrm{~N} / \mathrm{ha}$.
\end{abstract}

\section{Keywords}

Nitrogen Fertilizer, Grain Yield, Rice Quality, Chalkiness, Eating Quality

\section{Introduction}

Rice is one of the main grain crops in the world and constitutes a substantial proportion of the consumption and production of cereal. Currently, the climate for rice production is dramatically changed by artificial or natural factors, such as unreasonable cultivation and global warming, bringing severe challenges to the safety of rice production [1] [2] [3]. It is important to guarantee a stable rice yield in real-time environmental conditions for the food security of humanity. 
Simultaneously, with the development of economics and trade and the improvement of quality of life, the demand for higher quality rice is rapidly increasing. Therefore, it is quite important to sustainably cultivate rice with high yield and quality to meet the demands of society.

There are many factors affecting rice yield and quality, such as variety, accumulation temperature during the growth period, and relatively minor factors such as cultivation techniques (fertilizer rates, fertilization period, water management, etc.) [4] [5] [6] [7]. Due to the effect of increased yield brought by the application of nitrogen fertilizer, an increasing number of nitrogen fertilizers have been applied in rice production. However, recent results have shown that excessive long-term application of nitrogen fertilizers has not resulted in a significant increase in rice yield but a significant decrease in fertilizer utilization rate [8] [9], causing a series of problems, such as deterioration of soil properties, serious environmental pollution, and declined rice quality [10]. Therefore, an understanding of the interaction between the different nitrogen rates and nitrogen utilization rates and the quality and yield of rice is not only essential for optimizing rice production by the application of nitrogen but also important for protecting the environment.

In the past two decades, several studies have investigated the effect of nitrogen application rates on rice quality and yield, and it is generally considered that nitrogen application rates are positively related to grain yield [11], and rice milling quality and nutritional quality [12] and have negative effects on rice eating quality [10]. For the appearance quality, previous results varied due to different experimental locations and rice varieties [5] [13]. Although there has been a marked improvement in rice quality and yield in South China [10], little progress has been made in Northeast China, especially for japonica rice, which is widely planted in North China. In addition, previous research focuses vary among disciplines; for example, experts in agronomy have mostly studied the effects of different cultivation conditions on grain yield and limited quality indicators of rice [5], while experts in the food industry have focused on changes in quality indicators during postharvest rice storage [14]. However, the quality and storage performance of rice is closely associated with prenatal factors, so it is necessary to analyze rice quality in terms of both prenatal and postnatal factors. The qualities of rice are mainly divided into milling quality, appearance quality, cooking and eating quality and nutritional quality. Merchants mainly focus on the first two qualities, and consumers pay more attention to the latter two qualities. In fact, improvement in the quality of rice is a shared goal. Therefore, in this study, we conducted a detailed and comprehensive investigation of rice quality indicators in terms of a combination of preharvest fertilizer application rates and postharvest yield and quality of rice in northeast China.

In this paper, based on the local farmers' traditional fertilization rates, we systematically studied the effect of nitrogen fertilizer application rates on rice quality and yield from the perspective of a combination of nitrogen application rates and nitrogen utilization of rice and recommended the nitrogen rate for local rice 
cultivation, providing a theoretical basis for rice cultivation aimed at improving rice quality in Northeastern China and providing a direction for breeding in Northern China.

\section{Materials and Methods}

\subsection{Plant Materials and Experimental Design}

The experiment was conducted at Liaohe Delta, Panjin city, China $\left(122^{\circ} 14^{\prime} 17^{\prime \prime} \mathrm{N}\right.$, $\left.41^{\circ} 9^{\prime} 31 " \mathrm{E}\right)$, from 2017 to 2018 . The climate belongs to temperate semi humid monsoon climate type, with annual rainfall of $650 \mathrm{~mm}$, annual average temperature of $8^{\circ} \mathrm{C}-9^{\circ} \mathrm{C}$, frost free period of $165-170$ days. The soil is saline alkaline paddy soil with a pH of 8.2 and OM $22.6 \mathrm{~g} / \mathrm{kg}$. The rice variety was Yanfeng 47 , which is one of the main local varieties, this rice variety has compact plant type, strong stem, better resistances to fertilizer and lodging. The six nitrogen treatments had application rates of $0,160,210,260,315$, and $420 \mathrm{~kg} \mathrm{~N} / \mathrm{ha}$ based on the local farmer's traditional nitrogen application rate $(260 \mathrm{~kg} \mathrm{~N} / \mathrm{ha}$ ). Seeds were transplanted on May 25 and harvested on October 8. The size of each subplot was $50 \mathrm{~m}^{2}$. The transplanting density was $30 \mathrm{~cm} \times 18.2 \mathrm{~cm}$ with three seedlings in each hill. The experiment was conducted in three replicates.

In all treatments, nitrogen fertilizer was large granular urea, phosphate fertilizer was diammonium phosphate and superphosphate, and potassium fertilizer was chlorine sulfuric acid. Sixty percent of nitrogen was applied during the transplanting period, $30 \%$ of nitrogen was used as tilling fertilizer, and $10 \%$ of nitrogen was used as panicle fertilizer. Phosphorus $\left(90 \mathrm{~kg} \mathrm{P}_{2} \mathrm{O}_{5} / \mathrm{ha}\right)$ and potassium $\left(90 \mathrm{~kg} \mathrm{~K} \mathrm{~K}_{2} \mathrm{O} / \mathrm{ha}\right.$ ) were applied during the transplanting period. Other practices conformed to local recommendations.

\subsection{Determination of the Grain Yield and Nitrogen Use Efficiency of Rice}

Grain yield was determined by a harvest area of $1 \mathrm{~m}^{2}$, three hills of rice plants were randomly selected from each treatment, and each hill was used to determine the nitrogen content of rice shoots and grains by the Kjeldahl method. The calculation formulas are as follows:

$$
\begin{gathered}
\mathrm{NAG}(\mathrm{kg} / \mathrm{ha})=(\text { grains yield }((\mathrm{kg} / \mathrm{ha}) \times \mathrm{NG}) / 100) \\
\mathrm{NAS}(\mathrm{kg} / \mathrm{ha})=(\text { shoots yield }(\mathrm{kg} / \mathrm{ha}) \times \mathrm{NS}) / 100 \\
\mathrm{NAP}(\mathrm{kg} / \mathrm{ha})=\mathrm{NAG}+\mathrm{NAS} \\
\mathrm{NUC}(\%)=(\mathrm{NAPT}-\mathrm{NAPC}) \times 100 / \text { Nitrogen application rates }
\end{gathered}
$$

where NG is the nitrogen content of $100 \mathrm{~kg}$ grains, NS is the nitrogen content of $100 \mathrm{~kg}$ shoots, NAG is nitrogen accumulation in grains, NAS is nitrogen accumulation in shoots, NAP is nitrogen accumulation in plants (including rice shoots and grains in a hill rice), NAST is nitrogen accumulation in plants treated with nitrogen fertilizer, NAPC is nitrogen accumulation in plants treated with- 
out nitrogen fertilizer, and NUC is nitrogen use efficiency.

\subsection{Determination of Rice Quality Traits}

Harvested grains were dried under natural air until the moisture content was $14 \%$ for the next determination.

\subsubsection{Milling Quality}

The brown rice rate (BRR) and milled rice rate (MRR) were determined according to GB/T 21499-2008 [15]. A total of $150 \mathrm{~g}$ of paddy was crushed to obtain brown rice by a ridge mill (FC2K, Yamamoto, Japan), and then, the brown rice was milled by a milling machine (VP-32T, Yamamoto, Japan). Each treatment was repeated three times.

\subsubsection{Nutritional Components}

Brown rice was used to measure the total protein content (TPC) and amylose content (AC) by a near-infrared grating nutrient analyzer (DA7200, Perten, Sweden). The fat content (FC) was determined according to the Soxhlet extraction method described in GB5009.6-2016 [16].

\subsubsection{Appearance Quality}

The chalky rice rate (CRR), chalkiness (C) and head rice rate (HRR) were measured by an appearance quality analyzer (ES-1000, Shizuoka, Japan) according to GB/T 1354-2009 [17].

\subsubsection{Eating and Cooking Quality}

The hardness score (HS), viscosity score (VS) and taste score (TS) of the cooked rice were measured according to Champagne [18] by a rice taste analyzer (STA1B, Satake, Japan), which used optical principles to determine sensory characteristics such as the appearance, hardness, viscosity and balance and taste value of cooked rice. The full scores for the hardness and viscosity of the cooked rice were all 10, and the full score for taste value was 100 . In detail, $30 \mathrm{~g}$ of milled rice was cooked according to GB/T 15682-2008 [19], and then $8 \mathrm{~g}$ of cooked rice was pressed into rice cakes and measured with a rice taste analyzer.

\subsubsection{Pasting Properties}

The pasting property parameters of rice flour, such as peak viscosity (PV), trough viscosity (TV), final viscosity (FV), breakdown (BD), setback (SB), peak time (PET) and pasting temperature (PAT), were determined by a rapid viscosity analyzer (RVA-4, Newport Scientific, Australia).

\subsection{Data Statistics and Analysis}

All data were first processed using Excel 2003 and then analyzed for significance using SPSS 22 software by the Duncan method with a significance standard of 0.05. All tables were generated with Word 2003; graphs were plotted with Origin 8.5 . 


\section{Results}

\subsection{Effect of Nitrogen Fertilizer on the Grain Yield and Nitrogen Use Efficiency of Rice}

According to Figure 1, a relatively high yield of grain was achieved at nitrogen application rates of 210, 260 and $315 \mathrm{~kg} / \mathrm{ha}$, and the difference between the three nitrogen rates was not significant. Nitrogen deficiency ( $160 \mathrm{~kg} \mathrm{~N} / \mathrm{ha}$ ) and excess nitrogen $(420 \mathrm{~kg} \mathrm{~N} / \mathrm{ha})$ resulted in a significant decrease in grain yield. For nitrogen use efficiency, with the increase in nitrogen application rates, the nitrogen use efficiency first increased and then decreased, and the highest value (42\%) was reached at $210 \mathrm{~kg} \mathrm{~N} / \mathrm{ha}$. High nitrogen application rates (greater than $315 \mathrm{~kg} \mathrm{~N} / \mathrm{ha}$ ) reduced both the grain yield and nitrogen use efficiency of rice. Therefore, $210 \mathrm{~kg} \mathrm{~N} / \mathrm{ha}$ was recommended for the relatively better positive effects on guaranteeing a high grain yield, saving nitrogen resources and having less negative influences on the environment.

Different letters indicate the least significant differences within each column $(\mathrm{p}<0.05)$.

\subsection{Effect of Nitrogen Fertilizer on Rice Quality}

\subsubsection{Milling Quality}

Milling quality traits include the BRR, MRR and HRR. Compared with the no nitrogen application treatment, nitrogen application significantly increased the BRR (Figure 2) of rice and had little influence on the MRR. Both nitrogen deficiency and excess nitrogen significantly reduced the HRR, and only the appropriate nitrogen application rate (210 - $260 \mathrm{~kg} \mathrm{~N} / \mathrm{ha})$ maintained a superior HRR. The BRR, MRR and HRR first increased and then decreased with increasing nitrogen rates, and the highest values were all reached at $260 \mathrm{~kg} \mathrm{~N} / \mathrm{ha}$. The difference in milling quality traits between treatments with different nitrogen rates was not significant at nitrogen rates between $210 \mathrm{~kg} \mathrm{~N} / \mathrm{ha}$ and $260 \mathrm{~kg} \mathrm{~N} / \mathrm{ha}$. Therefore, $210 \mathrm{~kg} \mathrm{~N} / \mathrm{ha}$ was recommended to obtain high milling quality for rice cultivation.

Vertical error bars represent the standard deviation of the mean, and different letters indicate the least significant differences within each column $(\mathrm{p}<0.05)$.

\subsubsection{Nutritional Components}

TPC, AC and FC are considered to contribute much to the formation of rice quality. The differences in the nutritional components of rice treated with different nitrogen rates are shown in Figure 3. With the increase in nitrogen rates, the TPC increased significantly, AC decreased, and FC had little change. Only high nitrogen rates (more than $315 \mathrm{~kg} \mathrm{~N} / \mathrm{ha}$ ) decreased the AC significantly, and low nitrogen rates $(160 \mathrm{~kg} \mathrm{~N} / \mathrm{ha})$ increased the FC.

\subsubsection{Appearance Quality}

$\mathrm{CR}$ and $\mathrm{C}$ were negatively related to the appearance quality of rice, and only excess nitrogen application significantly improved the appearance quality of rice 
(Figure 4). Compared with no nitrogen, CR slightly increased at low nitrogen application rates (less than $260 \mathrm{~kg} \mathrm{~N} / \mathrm{ha}$ ) but significantly decreased under high nitrogen application rates (more than $260 \mathrm{~kg} \mathrm{~N} / \mathrm{ha}$ ). C significantly increased at low nitrogen application rates and significantly decreased under $420 \mathrm{~kg} \mathrm{~N} / \mathrm{ha}$ compared to without nitrogen application. Under different nitrogen application conditions, the change trend of rice $\mathrm{C}$ was consistent with the CR. Only $420 \mathrm{~kg}$ $\mathrm{N} /$ ha significantly reduced the CR and C compared with other nitrogen application rates, but further discussion combined with other quality traits is needed to recommend this as the local application rate because it is fast higher than the traditional application rate.

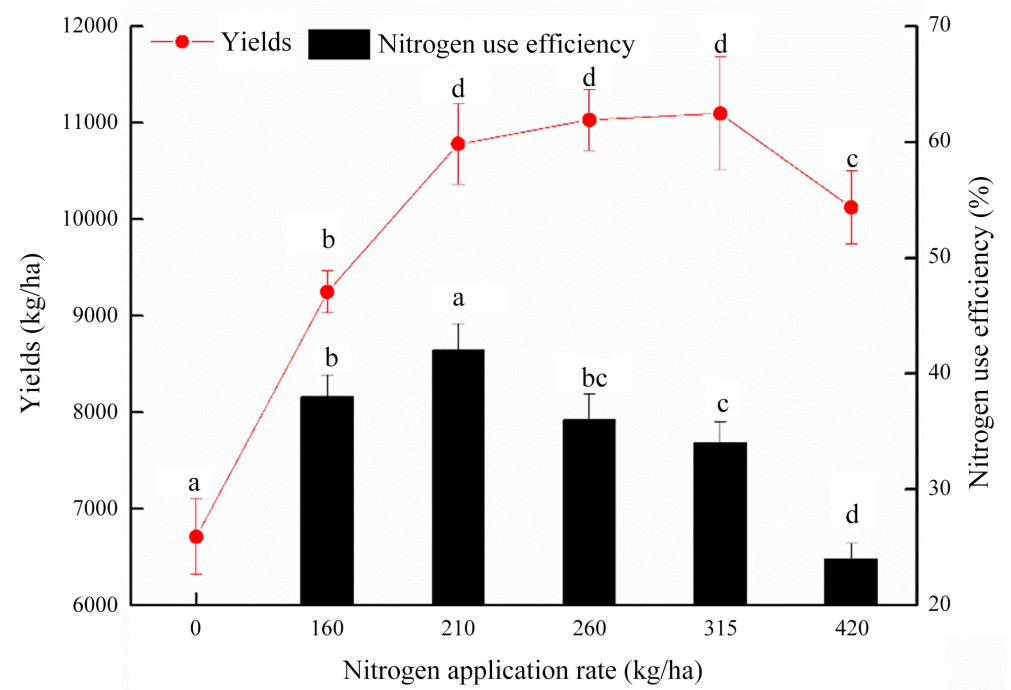

Figure 1. Effect of nitrogen application rates on the yields and nitrogen use efficiency of rice.

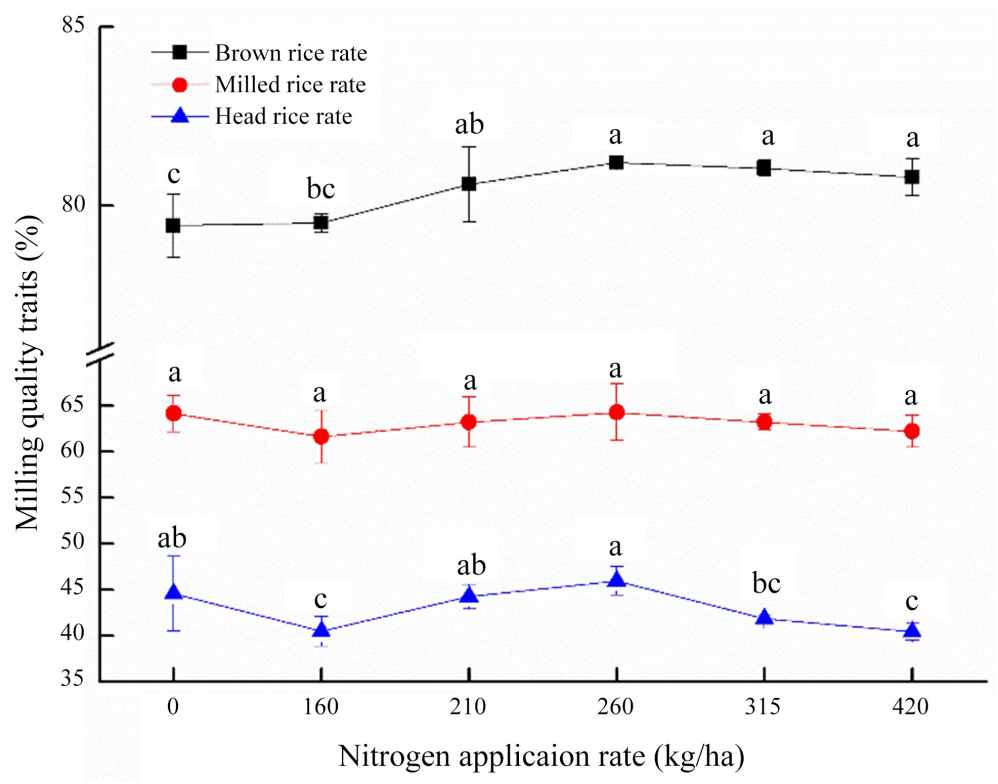

Figure 2. Effect of nitrogen application rates on rice milling quality. 


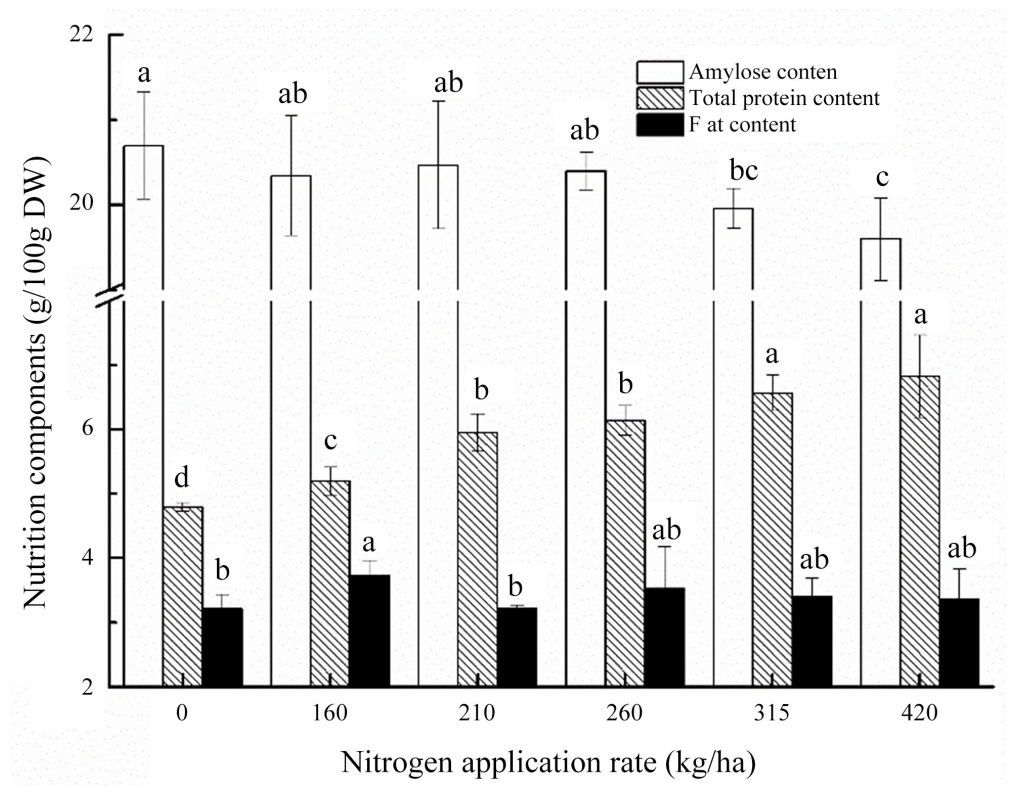

Figure 3. Effect of nitrogen application rates on rice nutrition components. Vertical error bars represent the standard deviation of the mean, and different letters indicate the least significant differences within each column $(\mathrm{p}<0.05)$.

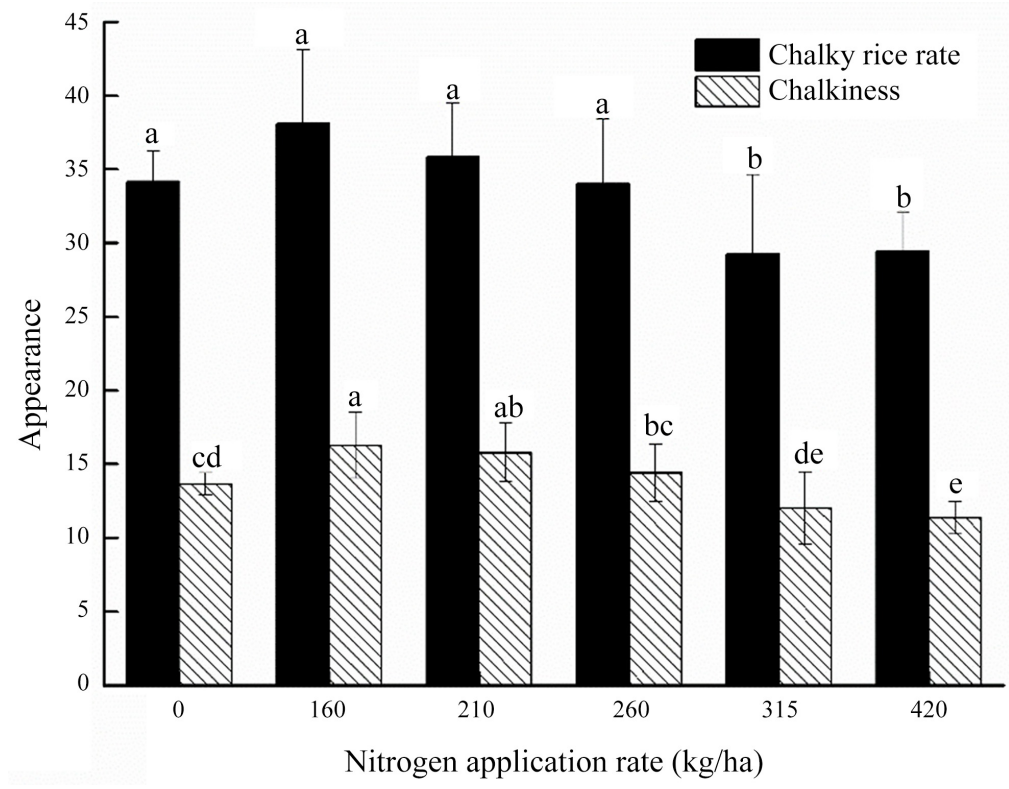

Figure 4. Effect of nitrogen application rates on rice appearance quality.

Vertical error bars represent the standard deviation of the mean, and different letters indicate the least significant differences within each column $(\mathrm{p}<0.05)$.

\subsubsection{Eating and Cooking Quality}

As shown in Figure 5, only $160 \mathrm{~kg} \mathrm{~N} /$ ha had no impact on the eating quality of rice, and other nitrogen levels significantly reduced the VS and increased the HS, resulting in a reduced TS. 
Vertical error bars represent the standard deviation of the mean, and different letters indicate the least significant differences within each column $(\mathrm{p}<0.05)$.

\subsubsection{Pasting Properties}

The parameters of the RVA profiles of rice flour are often regarded as characteristics of rice eating and cooking quality. The pasting properties of rice flour are displayed in Table 1 . Nitrogen deficiency (160 kg N/ha) slightly increased the $\mathrm{PV}, \mathrm{TV}$, and FV, while the other nitrogen application rates decreased them; in particular, excess nitrogen (420 kg N/ha) significantly reduced them, indicating that the viscosity of rice was reduced by nitrogen application, which was consistent with the result of VS (Figure 4). The residue parameters of RVA were slightly influenced by nitrogen application, indicating that nitrogen rates showed no impact on the cooking quality of rice, which was similar to our cooking time results (not displayed here).

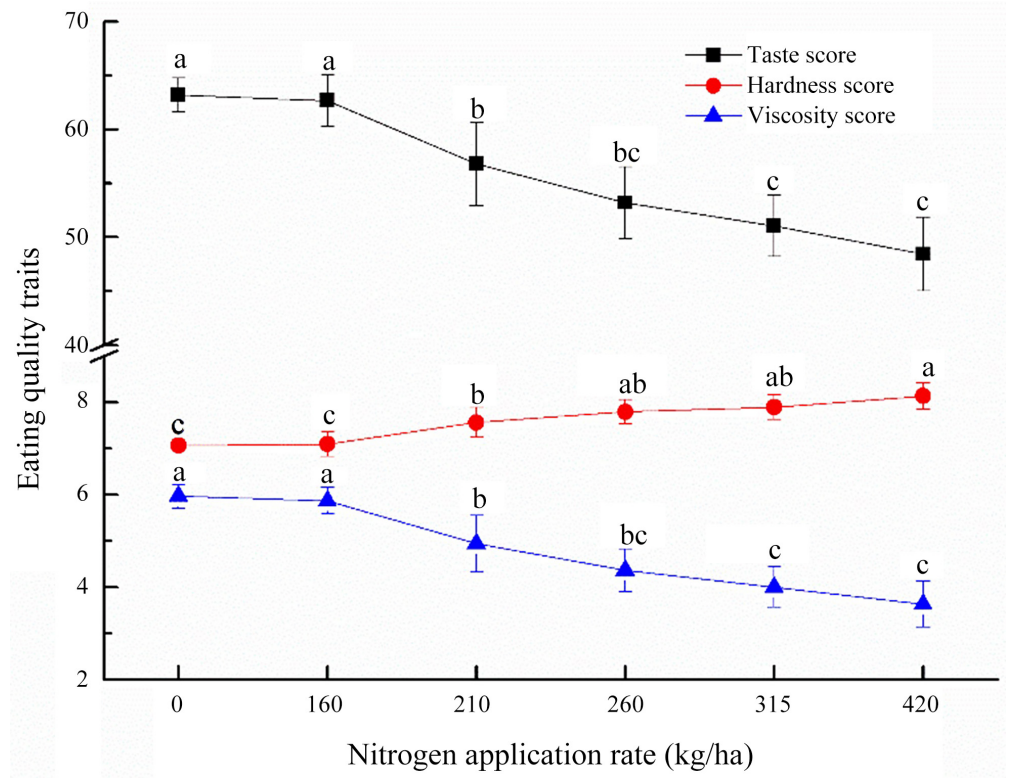

Figure 5. Effect of nitrogen application rates on rice eating quality.

Table 1. Effect of nitrogen application rate on RVA traits of rice flour ${ }^{\text {. }}$

\begin{tabular}{cccccccc}
\hline $\begin{array}{c}\text { Treatment } \\
(\mathrm{kg} \mathrm{N} / \mathrm{ha})\end{array}$ & $\begin{array}{c}\text { Peak viscosity } \\
(\mathrm{RVU})\end{array}$ & $\begin{array}{c}\text { Trough viscosity } \\
(\mathrm{RVU})\end{array}$ & $\begin{array}{c}\text { Final viscosity } \\
(\mathrm{RVU})\end{array}$ & $\begin{array}{c}\text { Breakdown } \\
(\text { RVU })\end{array}$ & $\begin{array}{c}\text { Setback } \\
(\mathrm{RVU})\end{array}$ & $\begin{array}{c}\text { Peak time } \\
(\mathrm{min})\end{array}$ & $\begin{array}{c}\text { Pasting } \\
\text { temperature }\left({ }^{\circ} \mathrm{C}\right)\end{array}$ \\
\hline 0 & $2878 \mathrm{ab}$ & $1977 \mathrm{a}$ & $2897 \mathrm{a}$ & 900 & 19 & 6.4 & 72.9 \\
160 & $3003 \mathrm{a}$ & $1954 \mathrm{a}$ & $2920 \mathrm{a}$ & 1048 & -83 & 6.3 & 72.7 \\
210 & $2855 \mathrm{ab}$ & $1887 \mathrm{ab}$ & $2830 \mathrm{ab}$ & 973 & -25 & 6.3 & 72.7 \\
260 & $2816 \mathrm{ab}$ & $1882 \mathrm{ab}$ & $2808 \mathrm{ab}$ & 928 & -7.66 & 6.3 & 73.5 \\
315 & $2727 \mathrm{ab}$ & $1826 \mathrm{ab}$ & $2765 \mathrm{ab}$ & 901 & 38 & 6.3 & 73.3 \\
420 & $2600 \mathrm{~b}$ & $1683 \mathrm{~b}$ & $2612 \mathrm{~b}$ & 917 & 11.33 & 6.3 & 73.3 \\
\hline
\end{tabular}

${ }^{a}$ Note: Difference letters represent significant differences at the $<0.05$ level. 


\section{Discussion}

To achieve sustainable development of rice with high quality and yield, this study researched the effect of nitrogen application rates on rice production from the perspective of rice plant nitrogen use efficiency, rice quality and grain yield; recommended optimal nitrogen application rates; analyzed the obstacle factors for cultivating high quality and yield rice, such as rice appearance quality and eating quality; and suggested that it is urgent for experts from different fields to struggle for more reasonable rice production together, such as breeding and agronomy and food science.

\subsection{Recommended Reasonable Nitrogen Application Rate}

With the development of society, Chinese agriculture has been considered to have sustainable rice production, which affects not only grain yields but also rice quality and environmentally friendly cultivation. In this study, with the increase in the nitrogen application rate, the milling quality, appearance quality, yield and nitrogen use efficiency of rice first increased and then decreased; the protein content increased; and the eating quality and AC decreased. These results, except for nitrogen use efficiency and appearance quality, were all consistent with a previous study [20] [21] [22] [23].

Our results for nitrogen use efficiency were not the same as those of Zhu, which showed that nitrogen use efficiency decreased with increasing nitrogen application rate [5], possibly because of the difference in soil properties and basic fertility between Panjin and Yangzhou [24]. For appearance quality, the difference between our results and Zhu's study will be analyzed in the subsequent sections.

These results revealed that it is impossible to control the application of nitrogen fertilizer to reach the best levels for the quality, yield and nitrogen use efficiency of rice. In addition, moderate nitrogen rates $(210-260 \mathrm{~kg} \mathrm{~N} / \mathrm{ha})$ had a relatively high nitrogen use efficiency, rice yield, milling quality and nutritional quality. The parameters of rice treated with $210 \mathrm{~kg} \mathrm{~N} / \mathrm{ha}$ were not significantly different from those of rice treated with $260 \mathrm{~kg} \mathrm{~N} / \mathrm{ha}$. Therefore, we recommended a nitrogen application rate of $210 \mathrm{~kg} \mathrm{~N} / \mathrm{ha}$, which was $20-60 \mathrm{~kg} \mathrm{~N} / \mathrm{ha}$ lower than that in a previous study [5] [25]. Zhu planted Nanjing 9108 and Nanjing 5055 in Yangzhou city $\left(119^{\circ} 42^{\prime} \mathrm{E}, 32^{\circ} 39^{\prime} \mathrm{N}\right)$ and recommended a nitrogen application of $270 \mathrm{~kg} \mathrm{~N} / \mathrm{ha}$ for optimal rice quality and grain yield of super rice [5]. Qiao recommended a nitrogen rate of $232-257 \mathrm{~kg} \mathrm{~N} / \mathrm{ha}$ for superior levels of nitrogen utilization and grain yield [25] after performing experiments in Yixing city $\left(119^{\circ} 8^{\prime}-121^{\circ} 5^{\prime} \mathrm{E}, 30^{\circ} 5^{\prime}-32^{\circ} 8^{\prime} \mathrm{N}\right)$. Our study was carried out in Panjin city $\left(41^{\circ} 9^{\prime} \mathrm{E}, 122^{\circ} 14^{\prime} \mathrm{N}\right)$, so this reduction may be explained by the different varieties of rice in southern and northeastern China responding differently to nitrogen, owing to the dramatic difference in temperature and light between the two sites.

However, in our study, rice was treated with $210 \mathrm{~kg} \mathrm{~N} / \mathrm{ha}$ in Panjin, and the 
rice eating quality and appearance quality were inevitably reduced. Therefore, improving the quality of rice under appropriate nitrogen rates should be the next focus of agronomy, food and breeding experts.

\subsection{Negative Effect of Nitrogen on Rice Eating Quality}

Eating quality is one of the main qualities focused on by consumers. It is well known that nitrogen application had a negative effect on rice eating quality owing to the increased hardness and decreased viscosity of cooked rice [5] [26] [27], which were also observed in our study, but the minimum nitrogen application rate that could significantly reduce rice eating quality was different from that in a previous study [5].

Our results showed that the application of nitrogen rates over $160 \mathrm{~kg} \mathrm{~N} / \mathrm{ha}$ significantly reduced the eating quality of rice. Zhu suggested that rice eating quality decreases faster when the nitrogen application rate exceeds $262.5 \mathrm{~kg} \mathrm{~N} / \mathrm{ha}$ [5]. The difference may be related to different rice varieties and growth areas. Yangzhou $\left(119^{\circ} 42^{\prime} \mathrm{E}, 32^{\circ} 39^{\prime} \mathrm{N}\right)$ had a higher average temperature in the rice growth period than Panjin $\left(122^{\circ} 14^{\prime} \mathrm{N}, 41^{\circ} 9^{\prime} \mathrm{E}\right)$, causing higher nitrogen loss and lower nitrogen absorption for rice, which was consistent with Li's results for maize. He reported that high temperature had a negative effect on nitrogen use efficiency [28], resulting in a higher nitrogen application rate for a significant change in rice eating quality.

To relieve the adverse impact of nitrogen on rice eating quality, intensive studies have been undertaken to reveal the relationship between nitrogen and key factors of rice eating quality, which are generally acknowledged as the hardness and viscosity of cooked rice. It has been reported that nitrogen application increased rice protein content, especially for gluten; decreased AC, leading to an increase in the hardness of rice [29] [30] [31] [32]; and simultaneously decreased the leach amylopectin content, causing a decrease in the viscosity of rice [33] and ultimately resulting in a decline in the eating quality of rice. A similar trend in protein content and $\mathrm{AC}$ was found in this study. Therefore, to improve eating quality under nitrogen application, it is necessary to breed rice with a low protein content and high amylopectin content in the future.

In addition, a reliable method that can accurately evaluate the eating quality of rice is significant for considering the impact of nitrogen on rice eating quality. Currently, eating quality is mainly determined by the sensory characteristics of trained persons and machines [34]. Machines were divided into three categories according to their principles. First, the taste analyzer and grain analyzer displayed the results as scores obtained from rice components by the near infrared method. Second, texture profile analysis (TPA) and a rheometer were used to evaluate the texture parameters (hardness and viscosity) of cooked rice by squeezing it with a probe [35]. Third, RVA and differential scanning calorimetry (DSC) were used to assess the pasting properties of rice flour and indirectly reflect the properties of cooked rice. Due to their low cost, eating quality has 
mostly been determined by machines in previous studies.

In our study, the results from the taste analyzer showed that nitrogen application increased the HS and reduced the VS, leading to poor eating quality. Similarly, for the RVA, parameters related to viscosity, such as the PV, TV and FV, decreased; however, parameters related to the palatability and texture of cooked rice, such as the $\mathrm{BD}$ and $\mathrm{SB}$, were little affected by nitrogen rates, which contrasted with the results obtained by the taste analyzer. The difference may be caused by the difference in samples between milled rice flour and cooked rice, indicating that selecting for determining eating quality plays a pivotal role in the results and that there is a need for better machine methods.

\subsection{A Low Nitrogen Application Rate Reduced Rice Appearance Quality, While a High Nitrogen Rate Improved It}

$\mathrm{C}$ is the opaque part of rice, which is attributed to its poor appearance quality. Previous results regarding the effect of nitrogen application rates on the $\mathrm{CR}$ and $C$ varied from each other due to different varieties, locations, growth environments and cultivation methods of rice. Zhu believed that the application of nitrogen fertilizer increased the CR [5], while Chen agreed that nitrogen application effectively reduced the generation of chalky rice [13]. In this study, nitrogen deficiency increased the CR and C, and excessive nitrogen (315 - $420 \mathrm{~kg} \mathrm{~N} / \mathrm{ha}$ ) reduced the CR significantly, which was similar to Dou $\left(119^{\circ} 28^{\prime} 21^{\prime \prime} \mathrm{E}, 31^{\circ} 54^{\prime} 31^{\prime \prime} \mathrm{N}\right)$, Zhou $\left(123^{\circ} 24^{\prime} \mathrm{E}, 41^{\circ} 480^{\prime} \mathrm{N}\right)$ and Brandon's results [7] [20] [36]. These diversity results revealed that the effect of nitrogen rates on rice $C$ may be influenced by environmental factors such as temperature, light, and water [37] [38] [39], indicating that it was not reasonable to improve rice appearance quality just by controlling nitrogen application rates.

To improve rice appearance quality, the factors influencing rice $\mathrm{C}$ and its mechanism were explored in other studies, and the results showed that the occurrence of rice $\mathrm{C}$ was related to many biological metabolic pathways, such as carbon and nitrogen metabolism, scavenging of reactive oxygen species, infiltration, cell wall synthesis and mineral ion homeostasis [40] [41] [42] [43] [44]. Due to its extreme complexity, an effective method for regulating $\mathrm{C}$ formation has not been discovered. Therefore, the main physiological metabolic regulators of chalk formation in each metabolic pathway should be the focus of future research.

Except for environmental factors, variety was reported as a key factor for the different appearance qualities of rice [45]. Therefore, breeding rice with better appearance quality may be a more efficient method than controlling environmental factors for improving rice appearance quality. Currently, for the factors that may impact rice $C$, most research is considered from the perspective of preharvest factors such as environmental factors (light, temperature, water) and field management (fertilizer application rate, irrigation). The same limitation existed in this paper, but few studies have examined postharvest factors such as storage conditions (time, temperature, humidity, and package). The exploration of the impact of postharvest factors on rice $\mathrm{C}$ may contribute to new possibilities 
in regulating rice appearance quality in the future.

\section{Conclusion}

The optimal level of rice quality and yield could not be achieved under the same nitrogen rate, but superior levels of nitrogen use efficiency, grain yield, milling quality and nutritional quality of rice could be achieved under $210 \mathrm{~kg} \mathrm{~N} / \mathrm{ha}$. For the best rice eating quality, the nitrogen rates must be controlled within $160 \mathrm{~kg}$ $\mathrm{N} / \mathrm{ha}$, and rice appearance quality only significantly improved when it exceeded $260 \mathrm{~kg} \mathrm{~N} / \mathrm{ha}$. Moreover, excessive nitrogen contemporarily reduced the nitrogen utilization, yield and quality of rice. Further considerations of breed and cultivation or postharvest factors aimed at improving eating and appearance quality are required.

\section{Conflicts of Interest}

The authors declare no conflicts of interest regarding the publication of this paper.

\section{Funding}

This work was supported by grants from the National Key Research and Development Program of China (grant no. 2018YFD0300300), and Science and Technology Innovation Talents Training Project of Liaoning Province (grant no. XLYC1802044).

\section{References}

[1] Jagadish, S., Murty, M. and Quick, W. (2015) Rice Responses to Rising Temperatures-Challenges, Perspectives and Future Directions. Plant Cell and Environment, 38, 1686-1698. https://doi.org/10.1111/pce.12430

[2] Lenka, S., Rajendiran, C.M., Dotaniya, M. and Saha, J. (2016) Impacts of Fertilizers Use on Environmental Quality.

[3] Zhao, X.Q. and Fitzgerald, M. (2013) Climate Change: Implications for the Yield of Edible Rice. PLoS ONE, 8, e66218. https://doi.org/10.1371/journal.pone.0066218

[4] Laenoi, S., Rerkasem, B. and Lordkaew, S. (2018) Seasonal Variation in Grain Yield and Quality in Different Rice Varieties. Field Crops Research, 221, 350-357. https://doi.org/10.1016/j.fcr.2017.06.006

[5] Zhu, D.W., Zhang, H.C., Guo, B.W., Xu, K., Dai, Q.G., Wei, H.Y., Gao, H., Hu, Y.J., Cui, P.Y. and Huo, Z.Y. (2017) Effects of Nitrogen Level on Yield and Quality of Japonica Soft Super Rice. Journal of Integrative Agriculture, 16, 1018-1027. https://doi.org/10.1016/S2095-3119(16)61577-0

[6] Cao, X.M., Sun, H.Y., Wang, C.G., Ren, X.J., Liu, H.F. and Zhang, Z.J. (2017) Effects of Late-Stage Nitrogen Fertilizer Application on the Starch Structure and Cooking Quality of Rice. Journal of the Science of Food and Agriculture, 98, 2332-2340. https://doi.org/10.1002/jsfa.8723

[7] Zhou, C.C., Huang, Y.C., Jia, B.Y., Wang, Y., Wang, Y., Xu, Q., Li, R.F., Wang, S. and Dou, F.G. (2018) Effects of Cultivar, Nitrogen Rate, and Planting Density on Rice-Grain Quality. Agronomy, 8, 246. https://doi.org/10.3390/agronomy8110246 
[8] Zhu, J., Li, X., Christie, P. and Li, J. (2005) Environmental Implications of Low Nitrogen Use Efficiency in Excessively Fertilized Hot Pepper (Capsicum frutescens L.) Cropping Systems. Agriculture Ecosystems and Environment, 111, 70-80. https://doi.org/10.1016/j.agee.2005.04.025

[9] Ju, X.T., Xing, G.X., Chen, X.P., Zhang, S.L., Zhang, L.J., Liu, X.J., Cui, Z.L., Yin, B., Christie, P. and Zhu, Z.L. (2009) Reducing Environmental Risk by Improving N Management in Intensive Chinese Agricultural Systems. Proceedings of the National Academy of Sciences, 106, 3041-3046. https://doi.org/10.1073/pnas.0813417106

[10] Gu, J.F., Chen, J., Chen, L., Wang, Z.Q., Zhang, H. and Yang, J.C. (2015) Grain Quality Changes and Responses to Nitrogen Fertilizer of Japonica Rice Cultivars Released in the Yangtze River Basin from the 1950s to 2000s. The Crop Journal, 3, 285-297. https://doi.org/10.1016/j.cj.2015.03.007

[11] Tayefe, M., Gerayzade, A., Amiri, E. and Zade, A. (2014) Effect of Nitrogen on Rice Yield, Yield Components and Quality Parameters. African Journal of Biotechnology, 13, 91-105. https://doi.org/10.5897/AJB11.2298

[12] Leesawatwong, M., Jamjod, S., Kuo, J., Dell, B. and Rerkasem, B. (2005) Nitrogen Fertilizer Increases Seed Protein and Milling Quality of Rice. Cereal Chemistry, 82, 588-593. https://doi.org/10.1094/CC-82-0588

[13] Chen, T.T., Wilson, L.T., Liang, Q., Xia, G.M., Chen, W. and Chi, D.C. (2017) Influences of Irrigation, Nitrogen and Zeolite Management on the Physicochemical Properties of Rice. Archives of Agronomy and Soil Science, 63, 1210-1226. https://doi.org/10.1080/03650340.2016.1276286

[14] Bertotto, M.M., Gastón, A., Sánchez Sarmiento, G. and Gove, B. (2019) Effect of Drying Conditions on the Quality of IRGA 424 Rice. Journal of the Science of Food and Agriculture, 99, 1651-1659. https://doi.org/10.1002/jsfa.9349

[15] General Administration of Quality Supervision, Inspection and Quarantine of the People's Republic of China (2008) Standard for Quality Rice. Determinaton of the Potential Milling Yield from Paddy and from Husked Rice, GB/T 21499-2008, 1, 6.

[16] State Food and Drug Administration of the People's Republic of China (2016) National Food Safety Standards. Determination of Fat in Food, GB 5009.6-2016.

[17] General Administration of Quality Supervision, Inspection and Quarantine of the People's Republic of China (2009) Rice. Milled Rice, GB/T 1354-2009.

[18] Champagne, E.T., Richard, O.A., Bett, K., Grimm, C., Vinyard, B., Webb, B. McClung, A., Barton, F., Lyon, B. and Moldenhauer, K. (1996) Quality Evaluation of US Medium-Grain Rice Using a Japanese Taste Analyzer. Cereal Chemistry, 73, 290-294.

[19] General Administration of Quality Supervision, Inspection and Quarantine of the People's Republic of China (2008) Grain and Oil Inspection. Sensory Evaluation Method for Cooking Quality of Rice and Rice, GB/T 15682-2008.

[20] Grigg, B.C., Siebenmorgen, T.J. and Norman, R.J. (2016) Effects of Nitrogen Rate and Harvest Moisture Content on Physicochemical Properties and Milling Yields of Rice. Cereal Chemistry, 93, 172-181. https://doi.org/10.1094/CCHEM-06-15-0130-R

[21] Dilday, R. (1988) Effect of Nitrogen Fertilizer on Milling Quality of Rice (Oryza sativa). Journal of the Arkansas Academy of Science, 42, 26-27.

[22] Faraji, F., Esfahani, M., Kavousi, M., Nahvi, M. and Forghani, A. (2013) Effect of Nitrogen Fertilizer Levels on Fe and Protein Content, Grain Breakage and Grain Yield of Rice (Oryza sativa L. Cv. Khazar). Biharean Biologist, 7, 25-28.

[23] Firouzi, S. (2015) Grain, Milling, and Head Rice Yields as Affected by Nitrogen Rate 
and Bio-Fertilizer Application. Acta Agriculturae Slovenica, 105, 241-248. https://doi.org/10.14720/aas.2015.105.2.07

[24] Ye, Q., Zhang, H., Wei, H., Zhang, Y., Wang, B.F., Xia, K., Huo, Z.Y., Dai, Q.G. and $\mathrm{Xu}, \mathrm{K}$. (2005) Effects of Nitrogen Fertilizer on Nitrogen Use Efficiency and Yield of Rice under Different Soil Conditions. Acta Agronomica Sinica, 31, 14-22.

[25] Qiao, J., Yang, L.Z., Yan, T.M., Xue, F. and Zhao, D. (2012) Nitrogen Fertilizer Reduction in Rice Production for Two Consecutive Years in the Taihu Lake Area. Agriculture Ecosystems and Environment, 146, 103-112. https://doi.org/10.1016/j.agee.2011.10.014

[26] Singh, N., Pal, N., Mahajan, G., Singh, S. and Shevkani, K. (2011) Rice Grain and Starch Properties: Effects of Nitrogen Fertilizer Application. Carbohydrate Polymers, 86, 219-225. https://doi.org/10.1016/j.carbpol.2011.04.039

[27] Champagne, E.T., Bett-Garber, K.L., Thomson, J.L. and Fitzgerald, M.A. (2009) Unraveling the Impact of Nitrogen Nutrition on Cooked Rice Flavor and Texture. Cereal Chemistry, 86, 274-280. https://doi.org/10.1094/CCHEM-86-3-0274

[28] Li, Y., Li, Z., Cui, S., Chang, S.X., Jia, C.L. and Zhang, Q.P. (2019) A Global Synthesis of the Effect of Water and Nitrogen Input on Maize (Zea mays) Yield, Water Productivity and Nitrogen Use Efficiency. Agricultural and Forest Meteorology, 268, 136-145. https://doi.org/10.1016/j.agrformet.2019.01.018

[29] Martin, M. and Fitzgerald, M. (2002) Proteins in Rice Grains Influence Cooking Properties! Journal of Cereal Science, 36, 285-294. https://doi.org/10.1006/jcrs.2001.0465

[30] Li, H.Y., Prakash, S., Nicholson, T.M., Fitzgerald, M.A. and Gilbert, R.G. (2016) The Importance of Amylose and Amylopectin Fine Structure for Textural Properties of Cooked Rice Grains. Food Chemistry, 196, 702-711. https://doi.org/10.1016/j.foodchem.2015.09.112

[31] Zhu, D.W., Zhang, H.C., Guo, B.W., Xu, K., Dai, Q.G., Wei, C.X., Zhou, G.S. and Huo, Z.Y. (2017) Effects of Nitrogen Level on Structure and Physicochemical Properties of Rice Starch. Food Hydrocolloids, 63, 525-532.

https://doi.org/10.1016/j.foodhyd.2016.09.042

[32] Lu, S., Cik, T.T., Lii, C.Y., Lai, P. and Chen, H.H. (2013) Effect of Amylose Content on Structure, Texture and $\alpha$-Amylase Reactivity of Cooked Rice. LWT-Food Science and Technology, 54, 224-228. https://doi.org/10.1016/j.lwt.2013.05.028

[33] Li, H.Y., Lei, N.Y., Yan, S., Gao, M.Y., Yang, J.Y., Wang, J. and Sun, B.G. (2019) Molecular Causes for the Effect of Cooking Methods on Rice Stickiness: A Mechanism Explanation from the View of Starch Leaching. International Journal of Biological Macromolecules, 128, 49-53. https://doi.org/10.1016/j.ijbiomac.2019.01.113

[34] Kim, H., Kim, O.W., Kwak, H.S., Kim, S.S. and Lee, H.J. (2017) Prediction Model of Rice Eating Quality Using Physicochemical Properties and Sensory Quality Evaluation. Journal of Sensory Studies, 32, e12273. https://doi.org/10.1111/joss.12273

[35] Li, H.Y., Prakash, S., Nicholson, T.M., Fitzgerald, M.A. and Gilbert, R.G. (2016) Instrumental Measurement of Cooked Rice Texture by Dynamic Rheological Testing and Its Relation to the Fine Structure of Rice Starch. Carbohydrate Polymers, 146, 253-263. https://doi.org/10.1016/j.carbpol.2016.03.045

[36] Dou, Z., Tang, S., Li, G.H., Liu, Z.H., Ding, C.Q., Chen, L., Wang, S.H. and Ding, Y.F. (2017) Application of Nitrogen Fertilizer at Heading Stage Improves Rice Quality under Elevated Temperature during Grain-Filling Stage. Crop Science, 57, 2183-2192. https://doi.org/10.2135/cropsci2016.05.0350

[37] Tang, S., Zhang, H.X., Liu, W.Z., Dou, Z., Zhou, Q.Y., Chen, W.Z., Wang, S.H. and 
Ding, Y.F. (2019) Nitrogen Fertilizer at Heading Stage Effectively Compensates for the Deterioration of Rice Quality by Affecting the Starch-Related Properties under Elevated Temperatures. Food Chemistry, 277, 455-462.

https://doi.org/10.1016/j.foodchem.2018.10.137

[38] Yamaguchi, T., Yamakawa, H., Nakata, M., Kuroda, M. and Hakata, M. (2019) Suppression of Phospholipase D Genes Improves Chalky Grain Production by High Temperature during the Grain-Filling Stage in Rice. Bioscience Biotechnology and Biochemistry, 83, 1102-1110. https://doi.org/10.1080/09168451.2019.1580137

[39] Hatakeyama, Y., Masumoto-Kubo, C., Nonami, H., Morita, S., Hiraoka, K., Onda, Y., Nakashima, T., Nakano, H. and Wada, H. (2018) Evidence for Preservation of Vacuolar Compartments during Foehn-Induced Chalky Ring Formation of Oryza sativa L. Planta, 248, 1263-1275. https://doi.org/10.1007/s00425-018-2975-x

[40] Kaneko, K., Sasaki, M., Kuribayashi, N., Suzuki, H., Sasuga, Y., Shiraya, T., Inomata, T., Itoh, K., Baslam, M. and Mitsui, T. (2016) Proteomic and Glycomic Characterization of Rice Chalky Grains Produced under Moderate and High-Temperature Conditions in Field System. Rice, 9, 26. https://doi.org/10.1186/s12284-016-0100-y

[41] Lin, Z.M., Wang, Z.X., Zhang, X.C., Liu, Z.H., Li, G.H., Wang, S.H. and Ding, Y.F. (2017) Complementary Proteome and Transcriptome Profiling in Developing Grains of a Notched-Belly Rice Mutant Reveals Key Pathways Involved in Chalkiness Formation. Plant and Cell Physiology, 58, 560-573.

https://doi.org/10.1093/pcp/pcx001

[42] Lin, Z., Zhang, X., Wang, Z., Jiang, Y., Liu, Z., Alexander, D., Li, G., Wang, S. and Ding, Y. (2017) Metabolomic Analysis of Pathways Related to Rice Grain Chalkiness by a Notched-Belly Mutant with High Occurrence of White-Belly Grains. BMC Plant Biology, 17, 39. https://doi.org/10.1186/s12870-017-0985-7

[43] Lin, Z.M., Zhang, X.C., Yang, X.Y., Li, G.H., Tang, S., Wang, S.H., Ding, Y.F. and Liu, Z.H. (2014) Proteomic Analysis of Proteins Related to Rice Grain Chalkiness Using iTRAQ and a Novel Comparison System Based on a Notched-Belly Mutant with White-Belly. BMC Plant Biology, 14, 163.

https://doi.org/10.1186/1471-2229-14-163

[44] Mitsui, T., Yamakawa, H. and Kobata, T. (2016) Molecular Physiological Aspects of Chalking Mechanism in Rice Grains under High-Temperature Stress. Plant Production Science, 19, 22-29. https://doi.org/10.1080/1343943X.2015.1128112

[45] Zhou, L.J., Liang, S.S., Ponce, K., Marundon, S., Ye, G.Y. and Zhao, X.Q. (2015) Factors Affecting Head Rice Yield and Chalkiness in Indica Rice. Field Crops Research, 172, 1-10. https://doi.org/10.1016/j.fcr.2014.12.004 